\title{
AKTIVITAS INHIBITOR TIROSINASE PADA EKSTRAK ALGA COKELAT SARGASSUM SP. AGARDH ASAL PESISIR LHOK BUBON, KABUPATEN ACEH BARAT
}

\section{THE INHIBITORY TIROSINASE ACTIVITY TO BROWN ALGAE OF SARGASSUM SP. AGARDH EXTRACT FROM LHOK BUBON COAST, WEST OF ACEH REGENCY}

\author{
${ }^{1}$ Mohamad Gazali \\ ${ }^{1}$ Prodi Manajemen Sumberdaya Akuatik Fakultas Perikanan dan IImu Kelautan \\ Universitas Teuku Umar Meulaboh, Indonesia \\ Korespondensi Penulis : mohamadgazali@utu.ac.id
}

\begin{abstract}
Seaweeds are marine macro algae that can be found attach to the bottom shallow coastal waters with subsrate as attached media. There are three major groups of seaweeds namely brown algae (Phaeophyta), red (Rhodophyta) and green (Chlorophyta). Sargassum sp is one of brown algae which mostly found in the Lhok Bubon Coastal West of Aceh. Recently, exploration of marine macroalgae as bioactive sources was investigated. Seaweed contains bioactive compound which can serve as a defense from ultraviolet radiation that caused hyperpigmentation effect. The aiming of this study is to analyse the tyrosinase inhibitory activity of Sargassum sp extract from Lhok Bubon Coastal Area, West of Aceh. The results shown that the methanol extract of Sargassum sp possess phytochemical properties such as fenol, alkaloid and triterpenoid. Tyrosinase inhibitory activity of Sargassum sp methanol extract is the best extract which can be inhibit monophenolase with $I_{50}: 1111.49 \mu \mathrm{g} / \mathrm{ml}$ and $\mathrm{IC}_{50}=1582.31 \mu \mathrm{g} / \mathrm{ml}$ in diphenolase pathway with kojic acid as positive control. Moreover, etyl asetate and $n$-hexane extract have no activity of tyrosinase inhibitor. Therefore, new finding of tyrosinase inhibitor agent from marine macroalgae Sargassum sp give the fruitfull information for cosmeceutical industry.
\end{abstract}

Keywords : Lhok Bubon, Brown Algae, Sargassum sp, Tyrosinase Inhibitor

ABSTRAK

Rumput laut adalah makroalga laut yang ditemukan menempel pada perairan pesisir yang dangkal dengan substrat sebagai media menempel. Terdapat tigas kelompok rumput laut yakni alga cokelat (Phaeophyta), alga merah (Rhodophyta) dan alga hijau Chlorophyta. Sargassum sp merupakan salah satu alga cokelat yang kebanyakan ditemukan di pesisir Lhok Bubon Aceh Barat. Saat ini, eksplorasi makroalga laut sebagai sumber bioaktif sedang diinvestigasi. Rumput laut mengandung senyawa bioaktif dimana bisa berfungsi sebagai pertahanan dari radiasi ultraviolet yang menyebabkan efek hiperpigmentasi. Tujuan kajian ini adalah untuk menganalisis aktivitas inhibitor tirosinase ekstrak Sargassum sp yang memiliki sifat-sifat fitokimia seperti fenol, alkaloid, dan triterpenoid. Aktivitas inhibitor tirosinase ekstrak metanol Sargassum sp merupakan esktrak terbaik dimana dapat menghambat jalur monofenolase dengan nilai $\mathrm{IC}_{50}=1111.49 \mu \mathrm{g} / \mathrm{ml}$ dan $\mathrm{IC}_{50}=$ $1582.31 \mu \mathrm{g} / \mathrm{ml}$ pada jalur difenolase dengan asam kojat sebagai kontrol positif. Sementara itu, ekstrak etil asetat dan n-heksan tidak memiliki aktivitas inhibitor tirosinase. Oleh karena itu, penemuan baru agen inhibitor tirosinase yang berasal dari makroalga laut Sargassum $\mathrm{sp}$ memberikan informasi yang bermanfaat untuk industri kosmetik.

Kata Kunci : Lhok Bubon, Algae cokelat, Sargassum sp, Inhibitor Tirosinase

\section{PENDAHULUAN}

Warna kulit bergantung pada komponen pigmen menurut derajat yang bervariasi. Jaringan memiliki warna inheren kekuningan diakibatkan oleh kandungan karotena. Adanya hemoglobin $(\mathrm{Hb})$ beroksigen di dasar kapiler dermis memberikan warna kemerahan. Warna kecokelatan sampai kehitaman diakibatkan oleh variasi jumlah 
pigmen melanin, satu-satunya pigmen yang dihasilkan di kulit. Prinsip utama dari produk pencerah kulit ialah menghambat pembentukan melanin. Enzim merupakan biokatalis yang mampu meningkatkan laju reaksi kimia tertentu tanpa ikut bereaksi (Montgomery et al. 1993). Tirosinase merupakan enzim yang mengatur biosintesis melanin.

Pembentukan melanin dapat dihambat dengan cara menurunkan sintesis tirosinase atau menghambat aktivitasnya (Hartanti dan Setiawan, 2009). Enzim tirosinase bekerja mengubah tirosin menjadi 3,4dihidroksifenilalanin (DOPA) dan kemudian menjadi dopakuinon yang selanjutnya melalui beberapa tahap transformasi dikonversi menjadi melanin (Fitrie, 2004). Inhibitor tirosinase akan menghambat reaksi pencokelatan atau pembentukan melanin. Berbagai inhibitor tirosinase telah banyak digunakan dalam bahan kosmetik sebagai pencegah hiperpigmentasi di antaranya adalah asam askorbat, arbutin, asam kojat, merkuri, dan hidrokuinon. Dari beberapa senyawa tersebut, asam kojat memiliki efek inhibisi dan kestabilan paling besar, namun menurut Miyazawa dan Tamura (2007), asam kojat bersifat karsinogenik.

Dunia kelautan juga kaya akan sumber molekul bioaktif (Balboa et al., 2013). Diantara organisme laut, rumput laut merupakan organisme yang baik diekplorasi untuk berbagai macam senyawa bioaktif seperti metabolit sekunder, serat makanan, mineral, lipida, protein, asam lemak omega 3, asam amino esensial, polisakarida dan vitamin (Plaza et al., 2008). Senyawa ini memberikan berbagai bioaktivitas seperti antioksidatif, anti imflamasi, anti mikroba dan potensi anti kanker pada alga ini (Lee et al., 2013).

Genus Sargassum, jenis alga cokelat yang merupakan rumput laut cokelat tropis dan subtropis yang hidup pada daerah subtidal dan intertidal. Distribusi dan struktur populasi spesies sargassum sp dipengaruhi oleh suhu air, tingkat pasang surut, gerakan air, dan tipe substrat. Sargassum $\mathrm{sp}$ adalah salah satu dari tiga makroalga yang ditemukan di pesisir Lhok Bubon Aceh Barat. Penelitian tentang inhibitor tirosinase dan antioksidan bahan alam telah banyak diselidiki oleh para ilmuwan. Rumput laut merupakan salah satu bahan alam yang mengandung polifenol. Senyawa aktif ini utamanya dikandung oleh alga cokelat (Shibata et al., 2004 ; Firdaus et al., 2006 ; Nakai et al., 2006 ; Nahas et al., 2007 ; Ganesan et al., 2008 ; Chandini et al., 2008; Chew et al., 2008 ; Wang et al., 2009). Dalam kajian ini, peneliti bertujuan mengkaji aktivitas inhibitor tirosinase dari ekstrak algae cokelat Sargassum sp asal pesisir Lhok Bubon Kabupaten Aceh Barat.

\section{METODE PENELITIAN}

\section{Waktu dan Tempat}

Penelitian ini dilaksanakan pada Juli sampai Agustus 2017. Sampel Sargassum sp diambil dari Pesisir Lhok Bubon Kecamatan Samatiga Kabupaten Aceh Barat (Gambar 1). Proses ekstraksi dan analisis dilakukan di beberapa laboratorium IPB, yaitu: 
Laboratorium Karakteristik Bahan Baku Hasil Perairan dan Laboratorium Uji BiofarmakaPusat Studi Biofarmaka.

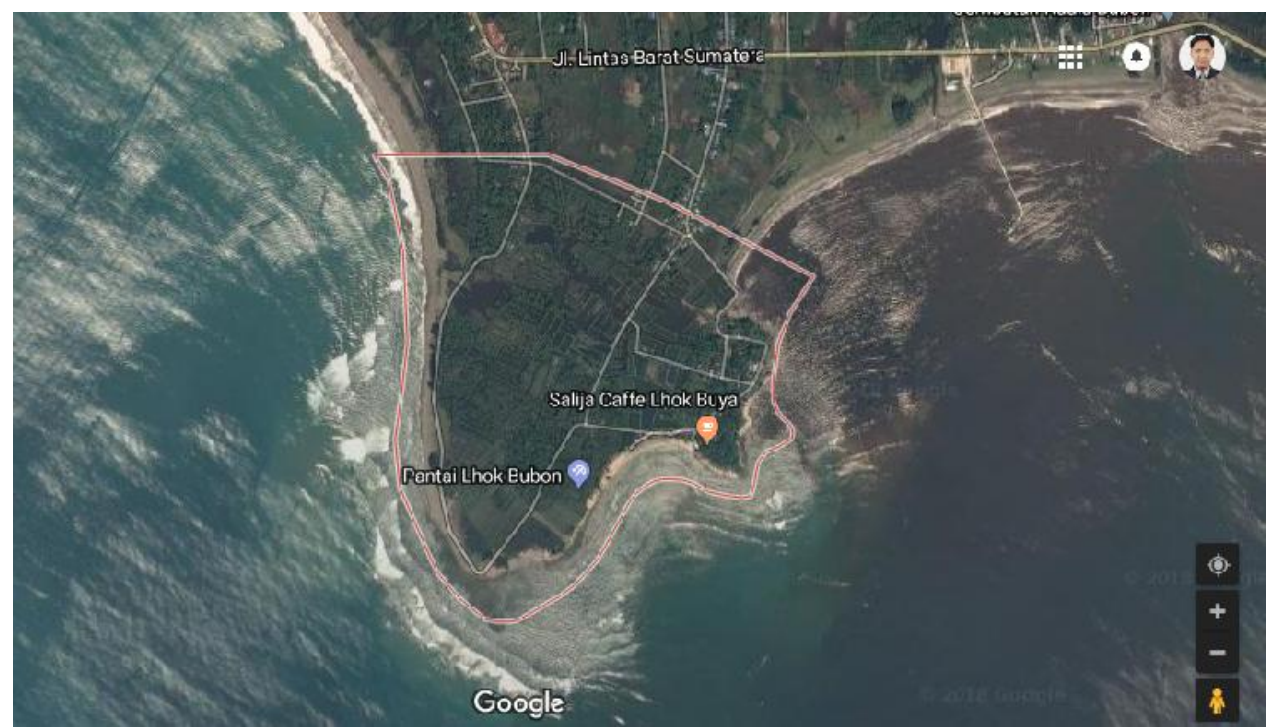

Gambar 1. Lokasi sampling

Sumber : (Google Maps, 2017)

\section{Bahan dan Alat}

Bahan utama yang digunakan dalam penelitian ini adalah Sargassum sp, nheksan, Metanol, etanol, kloroform p.a, etil asetat, aseton, dietil eter, dimetil sulfoksida (DMSO), bufer fosfat pH 6.5, dietil eter, serbuk Mg, $\mathrm{H} 2 \mathrm{SO}$ p.a, $\mathrm{NH} 4 \mathrm{OH}$, amil alkohol, $n$ heksana, diklorometana, $\mathrm{FeCl}_{3} 1 \%$, akuades, enzim tirosinase dari ja asam sulfat, pereaksi dragendorff, meyer, wagner, molisch, benedict, biuret, ninhidrin, kloroform, anhidra asetat, asam sulfat, magnesium, amil alkohol, dan $\mathrm{FeCl}_{2}$, enzim tirosinase dari jamur (Sigma, 333 unit $/ \mathrm{mL}$ ), asam kojat, dan L-DOPA $2 \mathrm{mM}$ atau L tirosin $2 \mathrm{mM}$.

Alat-alat yang digunakan dalam penelitian ini meliputi timbangan analitik, mortar, blender, erlenmeyer, sonikator, magnetic stirrer, vacuum rotary evaporator, botol vial, kertas saring, inkubator, spektrofotometer UV-Visible, ELISAN, plate microwell, sudip, alumunium foil, tabung reaksi, gelas ukur, pipet volumetrik, pipet mikro, gegep, tissue, kapas bebas lemak, kompor listrik, kantung plastik, tanur, cawan porselen, dan vorteks.

\section{Tahapan Penelitian}

Penelitian ini terdiri dari beberapa tahapan, yaitu tahap pengambilan dan preparasi sampel, serta tahap ekstraksi. Tahapan penelitian ini dapat dilihat pada Gambar 2. 


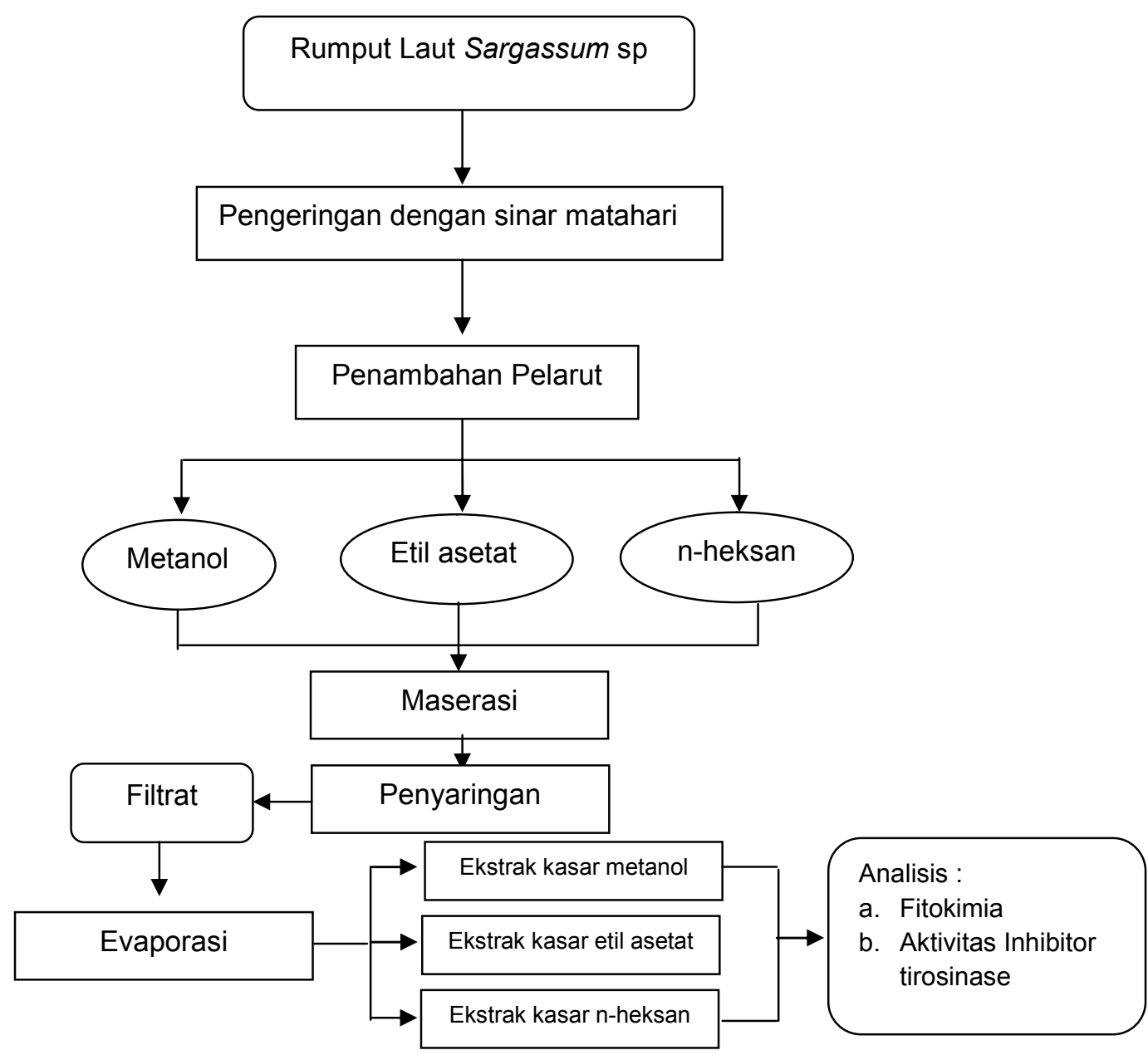

Gambar 2. Tahapan Penelitian

\section{Pengambilan dan preparasi sampel}

Sargassum sp yang terdapat di Pesisir Lhok Bubon selain tumbuh pada substrat berpasir, ditemukan berasosiasi dengan berbagai jenis rumput laut dan lamun. Spesies tersebut dipanen pada sore hari yaitu saat perairan surut untuk mempermudah proses pengambilan. Sampel Sargassum sp yang telah dipanen dicuci dengan air tawar. Sampel tersebut kemudian dimasukkan dalam kantong plastik dan ditambahkan sedikit air laut. Kantong plastik tersebut kemudian dimasukkan dalam cool-box dan ditambahkan es batu secukupnya. Preparasi sampel Sargassum sp dilakukan untuk menyiapkan sampel dalam bentuk segar dan kering sesuai dengan jumlah yang dibutuhkan dalam proses analisis. Pembuatan sampel kering dilakukan dengan mengeringkan sampel selama dua hari dengan sinar matahari pada pukul 10.00-13.00 WIB. Sampel tersebut kemudian diblender hingga halus.

\section{Ekstraksi sampel}

Ekstraksi Sargassum sp didasarkan pada metode Andayani et al. (2008) yang telah dimodifikasi. Proses tersebut menggunakan tiga jenis pelarut yaitu metanol (polar), 
etil asetat (semi polar) dan n-heksana (non-polar). Sampel kering Sargassum sp dihaluskan menggunakan blender dan ditimbang sebanyak10 gram. Sampel tersebut kemudian dimasukkan ke dalam erlenmeyer dan ditambahkan dengan pelarut sebanyak $160 \mathrm{ml}$ (1:16). Erlenmeyer berisi sampel dan larutan kemudian dimaserasi selama 48 jam dengan menggunakan orbit shaker. Sampel disaring dengan menggunakan kertas saring Whatman 42 sehingga diperoleh filtrat dan residu. Filtrat yang diperoleh kemudian dievaporasi menggunakan vacuum rotary evaporator pada suhu $40{ }^{\circ} \mathrm{C}$.

\section{Prosedur Analisis}

Analisis dilakukan terhadap sampel segar dan ekstrak kasar Sargassum sp. Analisis sampel segar meliputi analisis proksimat dan kadar abu tidak larut asam, serta analisis serat pangan. Analisis pada ekstrak kasar Sargassum sp meliputi senyawa fitokimia, dan aktivitas inhibitor Tirosinase.

\section{Kadar air (AOAC, 2005)}

Proses analisis diawali dengan mengeringkan cawan porselen kosong dalam oven selama 15 menit. Cawan tersebut kemudian didinginkan dalam desikator selama 20 menit, selanjutnya ditimbang. Sampel segar Sargassum sp sebanyak lima gram dimasukkan dalam cawan kemudian dikeringkan dalam oven pada suhu $100{ }^{\circ} \mathrm{C}$. Tekanan yang digunakan tidak lebih dari $100 \mathrm{mmHg}$. Proses pengovenan dilakukan selama lima jam atau sampai beratnya konstan. Cawan berisi sampel yang telah dioven didinginkan dalam desikator, selanjutnya ditimbang. Perhitungan kadar air menggunakan rumus berikut.

Kadar $\operatorname{air}(\%)=\frac{B-C}{B-A} \times 100 \%$

Keterangan :

$\mathrm{A}=$ berat cawan kosong $(\mathrm{g})$

$\mathrm{B}=$ berat cawan + sampel awal $(\mathrm{g})$

$\mathrm{C}=$ berat cawan + sampel kering $(\mathrm{g})$

\section{Kadar abu (AOAC, 2005)}

Cawan pengabuan dikeringkan dalam oven selama satu jam pada suhu $105{ }^{\circ} \mathrm{C}$. Cawan tersebut kemudian didinginkan selama 15 menit dalam desikator, selanjutnya ditimbang. Sampel sebanyak lima gram dimasukkan ke dalam cawan pengabuan dan dipijarkan di atas kompor listrik hingga proses tersebut tidak menghasilkan asap. Cawan tersebut kemudian dimasukkan ke dalam tanur pengabuan selama enam jam pada suhu $400{ }^{\circ} \mathrm{C}$. Cawan tersebut selanjutnya didinginkan dalam desikator, kemudian ditimbang. Penentuan kadar abu dihitung dengan menggunakan rumus berikut.

Berat abu $(\mathrm{g})=$ berat sampel dan cawan akhir $(\mathrm{g})$ - berat cawan kosong $(\mathrm{g})$ 


$$
\text { Kadar abu }(\%)=\frac{\text { berat abu }(\mathrm{g})}{\text { berat sampel }(\mathrm{g})} \times 100 \%
$$

\section{Kadar lemak (AOAC, 2005)}

Analisis kadar lemak dilakukan dengan menggunakan metode soxhlet. Labu lemak dikeringkan dalam oven, kemudian didinginkan dalam desikator dan ditimbang. Satu gram sampel dalam bentuk tepung ditimbang menggunakan saringan timbel yang sesuai ukurannya kemudian ditutup dengan kapas wool yang bebas lemak. Timbel yang berisi sampel diletakkan dalam alat ekstraksi soxhlet kemudian alat kondensor dipasang di atasnya dan labu lemak dibawahnya. Pelarut dietil eter atau n-heksana dituangkan secukupnya ke dalam labu lemak. Labu tersebut kemudian direfluks selama enam jam sampai pelarut yang turun ke labu lemak tidak berwarna. Pelarut hasil destilasi ditampung, kemudian labu lemak berisi lemak hasil ekstraksi dipanaskan dalam oven pada suhu $105{ }^{\circ} \mathrm{C}$. Labu tersebut kemudian didinginkan dalam desikator, selanjutnya ditimbang. Kadar lemak dihitung dengan rumus berikut.

$$
\text { Kadar lemak }(\%)=\frac{\mathrm{W}_{2}-\mathrm{W}_{1}}{\mathrm{~W}_{0}} \times 100 \%
$$

Keterangan :

$\mathrm{W}_{0}=$ Berat sampel $(\mathrm{g})$

$\mathrm{W}_{1}=$ Berat labu lemak kosong $(\mathrm{g})$

$\mathrm{W}_{2}=$ Berat labu lemak dengan lemak $(\mathrm{g})$

\section{Kadar protein (AOAC, 2005)}

Analisis kadar protein terdiri dari tiga tahap, yaitu destruksi, destilasi dan titrasi. Pengukuran kadar protein dilakukan dengan metode mikro Kjeldahl. Sampel ditimbang sebanyak 0,25 gram dimasukkan ke dalam labu Kjeldahl $100 \mathrm{ml}$. Sebanyak 0,25 gram Selenium dan $3 \mathrm{ml} \mathrm{H}_{2} \mathrm{SO}_{4}$ pekat serta sampel didekstruksi (pemanasan dalam keadaan mendidih) pada suhu $410{ }^{\circ} \mathrm{C}$ selama 1 jam sampai larutan jernih. Setelah dingin ditambahkan $50 \mathrm{ml}$ aquades dan $20 \mathrm{ml} \mathrm{NaOH} 40 \%$, lalu didestilasi dengan suhu destilator $100{ }^{\circ} \mathrm{C}$. Hasil destilasi ditampung dalam labu Erlenmeyer yang berisi campuran $10 \mathrm{ml} \mathrm{H} \mathrm{2 \%} \mathrm{dan} 2$ tetes indikator bromcherol green-methyl red berwarna merah muda (1:2). Setelah volume hasil tampungan (destilat) menjadi $40 \mathrm{ml}$ dan berwarna hijau kebiruan, destilasi dihentikan dan destilat dititrasi dengan $\mathrm{HCl}$ 0,10 $\mathrm{N}$ sampai berwarna merah muda. Perlakuan yang sama dilakukan juga terhadap blanko. Kadar protein dihitung dengan rumus sebagai berikut :

$$
\mathrm{N}(\%)=\frac{(\mathrm{ml} \mathrm{HCl}-\mathrm{ml} \text { blanko }) \times \mathrm{N} \mathrm{HCl} \mathrm{x} \text { faktor pengenceran } \mathrm{x} 14,007}{\mathrm{mg} \text { contoh } \mathrm{x} \text { faktor koreksi alat }} \times 100 \%
$$

Protein $(\%)=\mathrm{N}(\%) \times 6,25$ 


\section{Analisis rendemen (Andayani et al., 2008)}

Ekstrak Sargassum sp yang dihasilkan berdasarkan metode penelitian Andayani et al. (2008) yang dimodifikasi. Perhitungan rendemen ekstrak kasar menggunakan rumus sebagai berikut.

Rendemen ekstrak $(\%)=\frac{C-B}{A} \times 100 \%$

Keterangan :

$A=$ bobot awal sampel (gram)

$B=$ bobot botol kosong (gram)

$\mathrm{C}=$ bobot sampel+botol setelah ekstraksi (gram)

\section{Uji fitokimia (Harborne, 1987)}

Uji fitokimia bertujuan untuk mengetahui ada tidaknya komponen bioaktif yang terdapat pada sampel Sargassum sp. Uji fitokimia yang dilakukan meliputi uji alkaloid, steroid/triterpenoid, flavonoid, saponin, fenol hidrokuinon, dan tannin.

\section{Alkaloid}

Uji alkaloid dilakukan dengan melarutkan dalam beberapa tetes asam sulfat $2 \mathrm{~N}$ kemudian diuji dengan tiga pereaksi alkaloid yaitu, pereaksi dragendorff, pereaksi meyer, dan pereaksi wagner. Hasil uji positif diperoleh bila terbentuk endapan putih kekuningan dengan pereaksi meyer, endapan coklat dengan pereaksi wagner dan endapan merah hingga jingga dengan pereaksi dragendorff. Pereaksi meyer dibuat dengan menambahkan $1,36 \mathrm{HgCl}$ dengan $0,5 \mathrm{~g} \mathrm{KI}$ lalu dilarutkan dan diencerkan dengan akuades menjadi $100 \mathrm{ml}$ dengan labu takar. Pereaksi ini tidak berwarna. Pereaksi wagner berwarna coklat dibuat dengan cara $10 \mathrm{ml}$ akuades dipipet kemudian ditambahkan 2,5 gram iodin dan 2 gram kalium iodida lalu dilarutkan dan diencerkan dengan akuades menjadi $200 \mathrm{ml}$ dalam labu takar. Pereaksi dragendorff berwarna jingga dibuat dengan cara 0,8 gram bismut subnitrat ditambahkan dengan $10 \mathrm{ml}$ asam asetat dan $40 \mathrm{ml}$ air. Larutan ini dicampur dengan larutan yang dibuat dari 8 gram kalium iodida dalam $20 \mathrm{ml}$ air. Sebelum digunakan, 1 volume campuran ini diencerkan dengan 2,3 volume campuran $20 \mathrm{ml}$ asam asetat glasial dan $100 \mathrm{ml}$ air.

\section{Triterpenoid/steroid}

Sejumlah sampel dilarutkan dalam $2 \mathrm{ml}$ kloroform dalam tabung reaksi yang kering lalu ditambahkan 10 tetes anhidrat asetat dan 3 tetes asam sulfat pekat. Reaksi positif ditunjukkan dengan terbentuknya larutan berwarna merah untuk pertama kali kemudian berubah menjadi biru dan hijau. 


\section{Saponin (uji busa)}

Saponin dapat dideteksi dengan uji busa dalam air panas. Busa yang stabil selama 30 menit dan tidak hilang pada penambahan 1 tetes $\mathrm{HCl} 2 \mathrm{~N}$ menunjukkan adanya saponin.

\section{Fenol Hidrokuinon}

Satu gram sampel diekstrak dengan $20 \mathrm{ml}$ etanol $70 \%$. Larutan yang dihasilkan diambil sebanyak $1 \mathrm{ml}$ kemudian ditambahkan 2 tetes larutan $\mathrm{FeCl}_{3} 5 \%$. Reaksi positif ditunjukkan dengan terbentuknya warna hijau atau hijau biru.

\section{Flavonoid}

Sejumlah sampel ditambahkan serbuk magnesium $0,1 \mathrm{mg}$ dan $0,4 \mathrm{ml}$ amil alkohol campuran asam klorida $37 \%$ dan etanol 95\% dengan volume yang sama) dan 4 $\mathrm{ml}$ alkohol kemudian campuran dikocok. Reaksi positif ditunjukkan dengan terbentuknya warna merah, kuning atau jingga pada lapisan amil alkohol.

\section{Tanin}

Sejumlah sampel ditambahkan $\mathrm{FeCl}_{3}$ kemudian campuran dihomogenkan. Reaksi positif ditunjukkan dengan terbentuknya warna merah pada campuran.

\section{Uji inhibisi tirosinase}

Ekstrak $n$-heksana, etil asetat, dan metanol yang sudah dipartisi dengan etil asetat dilarutkan dalam DMSO hingga konsentrasi $10000 \mu \mathrm{g} / \mathrm{mL}$. Larutan stok kemudian disiapkan dengan melarutkan ekstrak ke dalam bufer fosfat $50 \mathrm{mM}(\mathrm{pH} 6.5)$ hingga diperoleh konsentrasi $2857 \mu \mathrm{g} / \mathrm{mL}$. Setelah itu, ekstrak dan asam kojat sebagai kontrol positif diuji mulai konsentrasi 7.81 hingga $2000 \mu \mathrm{g} / \mathrm{mL}$ dalam pelat tetes 96 sumur. Sebanyak $70 \mu \mathrm{L}$ ekstrak pengenceran ini masing-masing digabungkan dengan $30 \mu \mathrm{L}$ enzim tirosinase (Sigma, $333 \mathrm{unit} / \mathrm{mL}$ dalam bufer fosfat). Pelat diinkubasi pada suhu kamar selama 5 menit, kemudian ditambahkan $110 \mu \mathrm{L}$ substrat L-tirosin $2 \mathrm{mM}$ atau LDOPA $2 \mathrm{mM}$ dan diinkubasi kembali selama 30 menit pada suhu kamar. Larutan pada setiap sumur diukur dengan menggunakan multiwell plate reader pada panjang gelombang $492 \mathrm{~nm}$ untuk menentukan persen inhibisi dan nilai konsentrasi hambat $50 \%$ $\left(\mathrm{IC}_{50}\right)$. Persen inhibisi dihitung dengan cara membandingkan serapan sampel sebelum penambahan ekstrak $(A)$ dengan setelah penambahan ekstrak $(B)$ :

Inhibisi $(\%)=\frac{A-B}{A} \times 100 \%$ 


\section{HASIL DAN PEMBAHASAN}

\section{Komposisi Proksimat}

Komposisi alga cokelat Sargassum sp yang diuji meliputi kadar air, kadar abu, kadar lemak, kadar protein, dan kadar abu tidak larut asam dilakukan untuk menentukan kualitas awal bahan. Kadar karbohidrat dalam Sargassum sp diperoleh melalui perhitungan perhitungan by difference. Pengujian abu tidak larut asam Sargassum $\mathrm{sp}$ dilakukan karena alga cokelat tersebut tumbuh pada substrat berpasir. Cara perhitungan analisis proksimat Sargassum sp dapat dilihat pada Tabel 1.

Tabel 1. Komposisi Proksimat Sargassum sp

\begin{tabular}{lcc}
\hline \hline Komponen & (\% bb \pm SD) & (\% bb \pm SD) \\
\hline \hline Kadar Air & $10,54 \pm 0,25^{\mathrm{a}}$ & $28,20^{\mathrm{b}}$ \\
Kadar Abu & $52,74 \pm 0,53^{\mathrm{a}}$ & $33,74^{\mathrm{b}}$ \\
Lemak & $0,79 \pm 0,04^{\mathrm{a}}$ & $4,54^{\mathrm{b}}$ \\
Protein & $2,53 \pm 0,15^{\mathrm{a}}$ & $8,42^{\mathrm{b}}$ \\
\hline Keterangan : $^{\mathrm{a}}=$ & \\
& ${ }^{\mathrm{b}}=$ Gazali $(2017)$ &
\end{tabular}

Hasil pengujian komposisi proksimat alga cokelat Sargassum sp berdasarkan Tabel 1 menunjukkan nilai yang berbeda. Manivannan et al., (2009) menyatakan bahwa komposisi makroalga yang berbeda dipengaruhi oleh faktor lingkungan seperti suhu, salinitas, cahaya, dan nutrisi. Kadar air dalam Sargassum sp yang diteliti sebanyak $10,54 \%$. Nilai tersebut lebih banyak daripada kadar air Sargassum sp yang diteliti oleh Siregar (2017) yaitu 28,20\%. Menurut Abbas (2006), perbedaan kadar air dalam suatu bahan sangat ditentukan oleh kondisi lingkungan penyimpanan yang meliputi suhu dan kelembaban nisbi $(\mathrm{RH})$. Kadar air suatu bahan akan menjadi lebih tinggi saat $\mathrm{RH}$ tinggi sehingga bahan akan menyerap uap air dari udara (Muchtadi dan Ayustaningwarno 2010).

Sebagian besar bahan makanan, yaitu sekitar $96 \%$ terdiri dari bahan organik dan air. Sisanya terdiri dari unsur-unsur mineral. Unsur mineral juga dikenal sebagai zat organik atau kadar abu. Bahan organik terbakar dalam proses pembakaran tetapi zat anorganiknya tidak, sehingga disebut abu (Winarno 2008).

Kadar abu Sargassum sp yang diteliti sebanyak 52,74 \%, jumlah tersebut lebih sedikit daripada hasil penelitian Siregar (2017) yaitu 33,74\%. Hal tersebut dapat disebabkan karena perbedaan perlakuan seperti proses pencucian terhadap sampel yang diteliti. Lama pencucian dapat mengurangi serbuk halus yang terdapat dalam sampel yang diteliti. Mappiratu (2009) menyatakan bahwa jumlah abu tidak larut asam dalam suatu bahan yang disyaratkan oleh FAO, maksimal 1\%. Kadar abu tidak larut asam menunjukkan adanya kontaminasi residu mineral atau logam yang tidak dapat larut dalam asam. 
Kadar lemak Sargassum sp yang diteliti sebanyak 0,79\%, sedangkan hasil penelitian Siregar (2017) yaitu 4,54 \%. Hal ini menunjukkan bahwa kadar lemak dalam Sargassum sp sangat rendah. Kadar protein Sargassum sp juga menunjukkan jumlah yang tidak banyak. Kadar protein Sargassum sp yang diteliti yaitu 2,53\%. Jumlah tersebut tidak jauh berbeda dengan hasil penelitian Siregar (2017) yaitu 8,42\%. Perhitungan kadar karbohidrat Sargassum sp dilakukan dengan metode by difference dan diperoleh nilai sebesar 5,91\%. Rendahnya hasil uji proksimat tersebut mengindikasikan bahwa Sargassum sp tidak dapat digunakan sebagai sumber lemak, protein, dan karbohidrat.

\section{Rendemen}

Rendemen merupakan persentase jumlah komponen tertentu yang diekstraksi dari suatu bahan. Alga cokelat Sargassum sp yang telah dikeringkan diekstrak menggunakan pelarut metanol, etil asetat, dan n-heksana. Pengeringan bertujuan untuk menghindari proses pembusukan dan memudahkan terjadinya proses ekstraksi. Banyaknya air dalam bahan pangan sangat menentukan kesegaran dan daya awet bahan. Kadar air yang tinggi mengakibatkan mudahnya Rendemen merupakan persentase jumlah komponen tertentu yang diekstraksi dari suatu bahan. Alga cokelat Sargassum sp yang telah dikeringkan diekstrak menggunakan pelarut metanol, etil asetat, dan n-heksana. Pengeringan bertujuan untuk menghindari proses pembusukan dan memudahkan terjadinya proses ekstraksi. Banyaknya air dalam bahan pangan sangat menentukan kesegaran dan daya awet bahan. Kadar air yang tinggi mengakibatkan mudahnya

Menurut Drastinawati (2005), ekstraksi yang dilakukan pada daun kering menghasilkan rendemen yang lebih banyak daripada daun segar. Sel daun yang dikeringkan mengalami kerusakan atau pecah dan kandungan airnya sangat rendah, sehingga ekstraksi dengan pelarut organik menjadi lebih mudah dan memberikan hasil yang lebih banyak. Metode ekstraksi yang digunakan adalah ekstraksi tunggal. Menurut Sarastani et al. (2002), ekstraksi tunggal menghasilkan rendemen ekstrak tiga kali lebih banyak daripada menggunakan metode ekstraksi bertingkat. Rendemen ekstraksi Sargassum sp yang dihasilkan menggunakan jenis pelarut yang berbeda dapat dilihat pada Gambar 2.

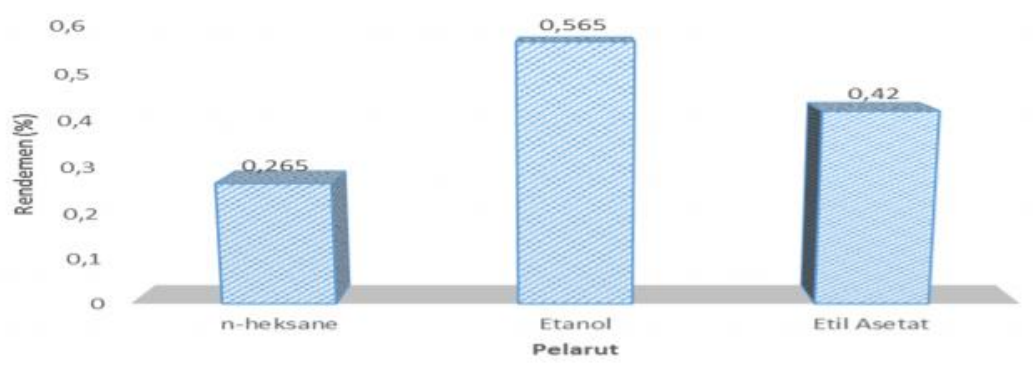

Gambar 2. Histogram rendemen ekstrak Sargassum sp 
Rendemen ekstrak Sargassum sp tertinggi terdapat pada ekstrak etanol yaitu $0,565 \mathrm{~g} / 100 \mathrm{~g}$. Rendemen ekstrak yang dihasilkan menggunakan pelarut etil asetat dan $\mathrm{n}$ heksan secara berurut yaitu 0,42 g/100g dan 0,265 g/100g. Ekstrak sampel yang dihasilkan menggunakan pelarut yang berbeda menunjukkan bahwa rendemen berkurang seiring dengan menurunnya tingkat kepolaran pelarut. Hal ini mengindikasikan bahwa Sargassum sp mengandung komponen bioaktif yang cenderung larut dalam pelarut polar. Proses ekstraksi beberapa tanaman herbal menggunakan pelarut yang berbeda yang dilakukan oleh Suryanto et al. (2008) menghasilkan rendemen terbanyak pada pelarut yang bersifat polar

\section{Fitokimia}

Rendemen ekstrak Sargassum sp mengandung fenol dengan jumlah yang cukup banyak sehingga dilakukan pengujian fitokimia. Metode yang digunakan mengacu pada Harborne (1987). Menurut Koche et al. (2010), fitokimia pada dasarnya dibagi menjadi dua kelompok, yaitu bagian primer dan bagian sekunder, tergantung pada fungsinya pada metabolisme tanaman. Bagian primer terdiri dari gula, asam amino, protein dan klorofil. Bagian sekunder terdiri dari alkaloid, terpenoid, saponin, komponen fenol, flavonoid, tannin dan lain-lain. Hasil uji fitokimia terhadap ekstrak rumput laut Sargassum sp yang diekstrak menggunakan pelarut yang berbeda dapat dilihat pada Tabel 2 .

Tabel 2. Senyawa fitokimia dalam ekstrak Sargassum sp

\begin{tabular}{llll}
\hline \hline & \multicolumn{3}{c}{ Ekstraksi } \\
\cline { 2 - 4 } \multicolumn{1}{c}{ Senyawa } & Etanol & etil asetat & n-heksan \\
\hline Alkaloid & - & - & - \\
Dragendorf & + & + & + \\
Meyer & - & + & - \\
Fenol & - & - & - \\
Steroid & - & - & - \\
Triterpenoid & - & - & + \\
\hline \hline
\end{tabular}

Keterangan : - = Tidak terdeteksi

$+=$ Terdeteksi

Hasil uji fitokimia berdasarkan Tabel 2 menunjukkan bahwa ekstrak Sargassum sp yang dihasilkan menggunakan tiga pelarut yang berbeda mengandung senyawa alkaloid, fenol dan triterpenoid. Hal ini disebabkan banyaknya kandungan fenol yang terdapat pada setiap ekstrak Sargassum sp. senyawa triterpenoid hanya terdeteksi pada ekstrak n-heksana. Senyawa steroid pada ketiga ekstrak terdeteksi semakin kuat seiring dengan meningkatnya tingkat kepolaran.

\section{Aktivitas Inhibitor Tirosinase}

Aktivitas inhibisi tirosinase dilakukan untuk mengetahui keberadaan dan ketidakberadaan aktivitas inhibisi tirosinase pada ekstrak etanol, etil asetat dan n-heksan. 
Aktivitas inhibisi tirosinase menunjukkan bahwa dengan nilai $\mathrm{IC}_{50}$ yaitu konsentrasi yang bisa menghambat $50 \%$ enzim tirosinase. Berdasarkan hasil bahwa ekstrak memiliki potensi sebagai inhibitor tirosinase (Gambar 3).

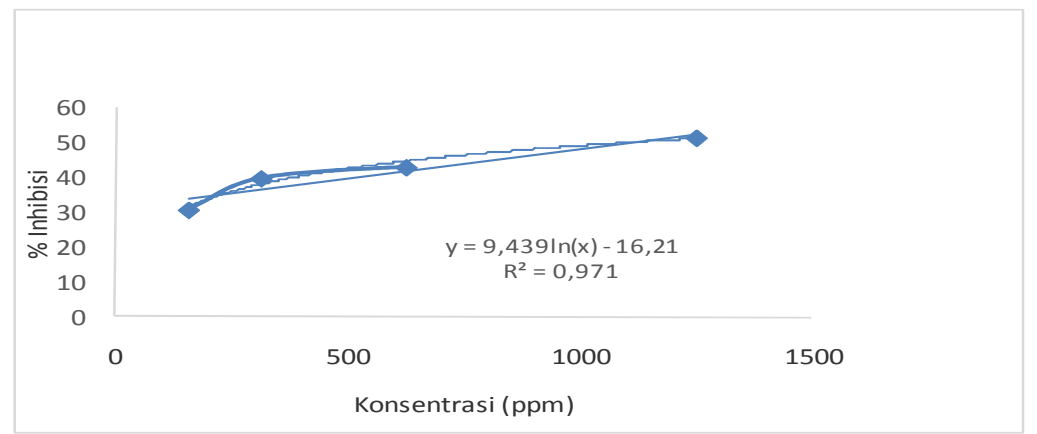

Gambar 3. Perbandingan Persentase inhibisi (\%) dan (ppm) pada jalur monofenolase

Pada Gambar 3 di atas menunjukkan jika konsentrasi (ppm) tinggi maka persentase inhibisi juga meningkat dengan nilai koefisien determinasi yaitu $\mathrm{y}=$ $9,4397 \ln (x)-16,21$ and $R$-squared $\left(R^{2}=0,9715\right)$. Ini menunjukkan bahwa variabel persentase inhibisidan konsentrasi (ppm) secara signifikan mempengaruhi sebanyak $84 \%$ pada jalur monofenolase.

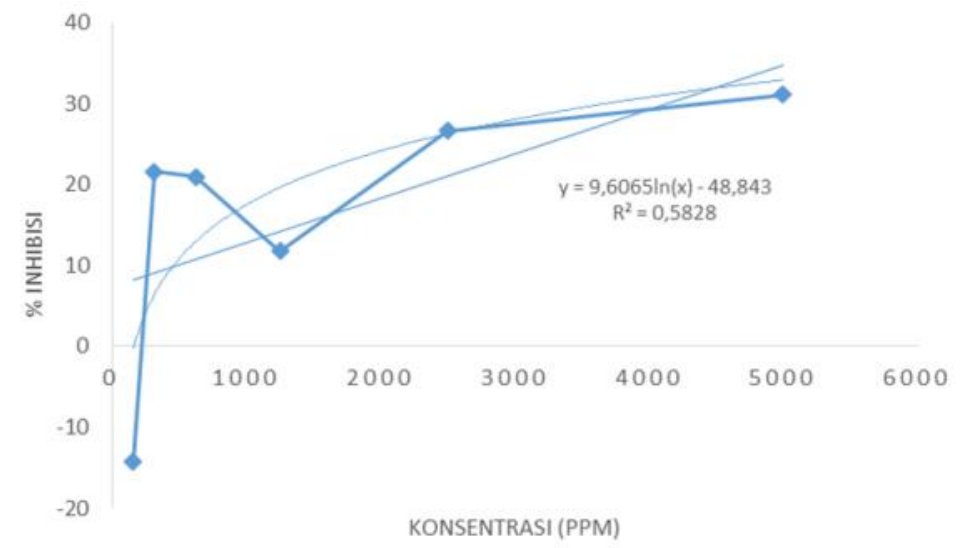

Gambar 4. Perbandingan persentase inhibisi (\%) dan konsentrasi (ppm) pada jalur difenolase

Perbandingan antara persentase inhibisi dan konsentrasi (ppm) pada jalur difenolase menunjukkan bahwa nilai koefisien determinasi yaitu $y=9,6065 \ln (x)-48,843$ and $R$-squared $\left(R^{2}=0,5828\right)$. Hal ini menunjukkan bahwa variabel persentase inhibisi dan konsentrasi (ppm) secara signifikan mempengaruhi sebesar $58 \%$ pada jalur monofenolase. Jadi, kita menyimpulkan bahwa persentase inhibisi dan konsentrasi (ppM) cukup berpengaruh positif dengan tingkat signifikan $95 \%$. 
Tabel 1. Nilai $I_{50}$ Aktivitas Inhibitor Tirosinase 3 ekstrak Sargassum $\mathrm{sp}$

\begin{tabular}{lcc}
\hline Ekstrak & $\mathrm{IC}_{50}(\mu \mathrm{g} / \mathrm{ml})$ & $\mathrm{IC}_{50}(\mu \mathrm{g} / \mathrm{ml})$ \\
\hline Etanol & Monofenolase & Difenolase \\
Etil Asetat & 1111.49 & 1582.31 \\
n-heksan & - & - \\
Asam Kojat & - & - \\
Keterangan : $\mathrm{IC}_{50}=$ & konsentrasi ekstrak yang bisa menghambat aktivitas tirosinase \\
sebesar $50 \% ;-$ : tidak mencapai & $50 \%$ inhibisi pada konsentrasi maksimum $5000 \mu \mathrm{gg} / \mathrm{ml}$.
\end{tabular}

Berdasarkan hasil analisis bahwa dengan pelarut yang berbeda meliputi ekstrak n-heksan, etil asetat, dan etanol. Kami melakukan skrining aktivitas inhibitor tirosinase (jalur monofenolase dan difenolase). Hasil analisis menunjukkan bahwa aktivitas inhibitor tirosinase ekstrak etanol Sargassum sp merupakan hasil terbaik yang mampu melakukan inhibisi aktivitas enzim tirosinase pada jalur monofenolase dengan nilai $\mathrm{IC}_{50}$ sebesar : $1111.49 \mu \mathrm{g} / \mathrm{ml}$ dan $\mathrm{IC}_{50}=1582.31 \mu \mathrm{g} / \mathrm{ml}$ pada jalur difenolase dengan asam kojat sebagai control positif.

Sementara itu, pada ekstrak etil asetat dan ekstrak n-heksan tidak memiliki aktivitas inhibitor tirosinase. Hal ini menunjukkan bahwa senyawa non-polar dan semipolar pada Sargassum sp tidak memiliki kemampuan pada aktivitas inhibisi tirosinase. Oleh karena itu, penemuan baru agen inhibitor tirosinase yang berasal dari Sargassum sp memberikan informasi yang bermanfaat untuk industri kosmetik. Perhatian utama pada eksplorasi Sargassum sp yang diselidiki oleh para ilmu untuk mengatasi masalah yang berkaitan dengan hiperpigmentasi kulit. Jadi, spesies Sargassum sp merupakan salah satu makroalga laut yang prospektif untuk kepentingan kosmetik. Hal ini masih dimanfaatkan secara tradisional oleh masyarakat pesisir untuk perawatan kulit.

\section{Kesimpulan}

\section{PENUTUP}

Berdasarkan hasil penelitian bahwa alga cokelat Sargassum sp ternyata memiliki potensi sebagai agen inhibitor tirosinase terutama pada jalur monofenolase. Akan tetapi alga cokelat Sargssum sp belum dimanfaatkan secara optimal oleh masyarakat pesisir sebagai bahan pencerah kulit.

\section{Ucapan Terima Kasih}

Penulis berterima kasih kepada mahasiswa Prodi MSA yang membantu dalam mengumpulkan sampel makroalga laut. Penulis juga mengucapkan terima kasih kepada laboran pusat studi biofarmaka LPPM-IPB dan Laboratorium Divisi Bahan Baku Hasil Perairan THP-IPB yang sudah menganalisis senyawa fitokimia dan lain-lainya. Penelitian ini didanai oleh Kemristek-DIKTI melalui hibah PEKERTI. 


\section{DAFTAR PUSTAKA}

Abbas A. 2006. Minuman Fungsional Berbahan Dasar The dan Kayu Manis untuk Penderita Diabetes. Prosiding pada Seminar Nasional Iptek Solusi Kemandirian Bangsa, 2 - 3 Agustus 2006. Bogor.

Andayani R, Lisawati Y, Maimunah. 2008. Penentuan Aktivitas Antioksidan,Kadar fenolat total, dan likopen pada buah tomat (Solanum lycopersium L). Jurnal Sains dan teknologi Farmasi. $13(1): 1-9$.

[AOAC] Association of Official Analytical Chemist. 2005. Official Method of Analysis of The Association of Official Analytical Chemist, inc

Balboa EM, Conde E, Moure A, et al (2013) In vitro antioxidant properties of crude extracts and compounds from brown algae. Food Chem 138:1764-1785. doi: 10.1016/j.foodchem.2012.11.026

Batubara, I., Darusman, L.K., Mitsunaga, T., Rahminiwati, M., Djauhari, E., 2010. Potency of Indonesia medicinal plant as tyrosinase inhibitor and antioxidant agent. Journal of Biological Science 10:138-144.

Chew YL, Lim YY, Omar M, Khoo Ks. 2008. Antioxidant axtivity of three edible seaweeds from two areas in South East Asia. Libbensmitted - Wissenschaft und Technology 41 : 1067 - 1072.

Chandini SK, Ganesan P, Bhaskar N. 2008. In vitro antioxidant activities of three selected brown seaweeds of India. Food Chemistry $107: 707$ - 713.

Drastinawati Y. 2005. Ekstraksi senyawa metabolit sekunder dari daun tanaman tutup bumi. Jurnal Sains dan Teknologi, $4: 16-19$.

Fitrie, A.A., 2004, Histologi dari melanosit. e-USU Repository Universitas Sumatera Utara 5:1-6

Firdaus M, Astawan M, Muchtadi D, Wresdiyati T, Waspadji S, Karyono SS. 2006. Efisiensi anti radikal florotannin Sargassum polycystum dan Sargassum echinocarpum, yang terlarut dalam berbagai pelarut polar. Jurnal Penelitian Perikanan 9: $157-161$.

Ganesan P, Kumar CS, Bhaskar N. 2008. Antioxidant properties of methanol extract and its solvent fraction obtained from selected Indian red seaweeds. Bioresource technology $99: 2717-2723$.

Hartanti, L., Setiawan, H.K., 2009, Inhibitory potential of some synthetic cinnamic acid derivatives towards tyrosinase enzyme, Indo Journal Chemistry 9:158-168.

Harborne J. 1987. Metode Fitokimia. Edisi ke-2. Kosasih Padmawinata, Penerjemah. Bandung : ITB-Press.

Koche D, Shirsat R, Imran S, Bhadange DG. 2010. Phytochemical screening of eight traditionally used ethnomedicinal plants from Akola District (MS) India. International Journal of Pharma and Bio Sciences 1(4) : 253 - 256.

Lee J-C, Hou M-F, Huang H-W, et al (2013) Marine algal natural products with antioxidative, anti-inflammatory, and anti-cancer properties. Cancer Cell Int 13:55. doi: 10.1186/1475-2867-13-55

Mappiratu. 2009. Kajian Teknologi pengolahan karaginan dari rumput laut Eucheuma cottonii skala rumah tangga. Media Litbang Sulteng 2(1) : $1-6$. 
Manivannan K, Thiumaran G, Karthikai G, Anantharaman P, Balasubramanian T. 2009. Proximate composition of different groupof seaweeds from Vedalai Coastal Waters (Gulf of Mannar) : Southeast Coast of India. Middle - East Journal of Scientific Research 4(2) : $72-77$.

Miyazawa, M, Tamura, N., 2007, Inhibitory compound of tyrosinase activity from the sprout of Polygonum hydropiper L. (Benitade), Biol Pharm Bull 30:595-597

Montgomery, R., Conway, T.W., Spector, A.A., 1993. Biokimia Beriorientasi pada Kasus Klinik. Staf Pengajar FKUI, penerjemah; Jakarta : Bina rupa Aksara

Muchtadi T, Ayustaningwarno F. 2010. Teknologi Proses Pengolahan Pangan. Bogor ; Alfabeta

Nakai M, Kageyama N, Nakahara K, Miki W. 2006. Phlorotannins as radical scavenger from extract of Sargassum ringgodianum. Marine Biotechnology 8: 409-414.

Plaza M, Cifuentes A, Ibanez E (2008) In the search of new functional food ingredients from algae. Trends Food Science Technology 19:31-39.doi: 10.1016/j.tifs.2007.07.012

Shibata T, Kawaguchi S, Hama Y. Inagaki M, Yamaguchi K. Nakamura T. 2004. Local and chemical distribution of phlorotannin in brown algae. Journal of Apply Phycology $16 ; 291-296$.

Sarastani D. Soekarto S, Muchtadi T, Fardiaz D. Apriyantono A. 2002. Aktivitas Antioksidan Ekstrak dan Fraksi Ekstrak biji atung Parinarium glabberimun Hassk. Jurnal Teknologi dan Industri Pangan 13 (2) : 149 - 156.

Suryanto E, Wehantou F, Raharjo S. 2008. Aktivitas penstabilan senyawa oksigen reaktif dari beberapa herbal. Jurnal Obat Bahan Alam 7(1) : $62-68$.

Wang T, Jonsdottir R, Olafsdottir G. 2009. Total Phenolic Compound, radical scavanging and metal chelation of extract from Icelandic Seaweed. Food Chemistry $116: 240$ -248 .

Winarno FG. 2008. Kimia Pangan dan Gizi. Bogor : M-Brio Press 